\title{
PENGETAHUAN PEDOMAN GIZI SEIMBANG DAN PERILAKU PILIHAN PANGAN PADA REMAJA PUTRI OVERWEIGHT: STUDI KUALITATIF
}

\author{
Vivi Cinthya Rotua Silalahi*, Dian Luthfiana Sufyan, Utami Wahyuningsih, Luh Desi Puspareni \\ Program Studi Gizi, Fakultas Ilmu Kesehatan, UPN Veteran Jakarta. J1. Limo Cinere, Depok, Jawa Barat 16515, Indonesia \\ * Penulis Penanggungjawab : E-mail: vivicinthya@upnvj.ac.id
}

\begin{abstract}
Background: Balanced nutrition guideline is one of the fundamental nutritional knowledge that girls alolescents have to know. In fact, balanced nutrition guideline is not familiar as 'complete menus of food' among girl adolescents. Improriate food choices behaviour to balanced nutrition guideline are increasing risk of overweight.

Objectives: This study aims to explore balanced nutrition guideline knowledge and factors that influencing food choice behavior among overweight girls adolescents.

Methods: Qualitative study method with indepth interview and observation were used in this study. Participants were chosen by purposive and snowball sampling, with total participants were 16. Source triangulation were conducted. Indepth interviews were conducted along with semi structured questions guide.

Results: Research showed all of the participants didn't familiar with balanced nutrition guideline. They were more familiar with 'complete menus of food'. Balanced nutrition guideline is not core factor that influencing their food choices. Having breakfast behaviour among participants is good enough, however high consumption of unhealthy food such as sugary food/beverages, salty and deep fried foods, and unbalanced food composition still occurred on participants.

Conclusions: Food choice behaviour among participants were impropriate to balanced nutrition guideline because of lack of exposure to the information. The most influencial factors were home, school, family environments and digital media. However, the internal factors that cause the food choice behaviour were food organoleptic and pocket money.
\end{abstract}

Keyword: adolescents; balanced nutrition; food; overweight

\begin{abstract}
ABSTRAK
Latar Belakang: Pedoman gizi seimbang merupakan pengetahuan gizi yang harus dipahami oleh remaja putri, namun konsep pedoman gizi seimbang masih belum sefamiliar 4 sehat 5 sempurna. Perilaku pilihan pangan tidak sesuai anjuran pedoman gizi seimbang meningkatkan risiko overweight.

Tujuan: Penelitian bertujuan untuk mengeksplorasi pengetahuan pedoman gizi seimbang dan faktor-faktor yang memengaruhi perilaku pilihan pangan pada remaja putri overweight.

Metode: Penelitian menggunakan metode kualitatif. Pengumpulan data dilakukan dengan wawancara mendalam dan triangulasi sumber. Jumlah subjek sebanyak 16 orang. Subjek penelitian ialah remaja dengan status gizi overweight dan normal (sebagai pembanding). Penelitian dilakukan selama 8 minggu.

Hasil: Hasil penelitian menunjukkan seluruh subjek penelitian lebih mengenal 4 sehat 5 sempurna daripada Pedoman Gizi Seimbang. Pedoman gizi seimbang bukan menjadi alasan utama pilihan pangan subjek. Kebiasaan selalu sarapan sudah cukup baik diantara subjek, namun masih tingginya konsumsi pangan tidak sehat seperti makanan/minuman manis, gurih/asin, gorengan, serta komposisi makanan tidak seimbang diantara subjek penelitian. Simpulan: Perilaku pilihan pangan remaja putri overweight belum sesuai dengan pedoman gizi seimbang disebabkan minimnya keterpaparan informasi PGS serta lebih kuatnya pengaruh faktor eksternal (lingkungan rumah, sekolah, keluarga, dan media digital) maupun faktor internal (organoleptik pangan dan uang saku) dalam pembuatan keputusan pilihan pangan subjek.
\end{abstract}

Kata kunci: gizi seimbang; overweight; pangan; remaja

\section{PENDAHULUAN}

Remaja merupakan masa peralihan antara kehidupan anak menuju dewasa. Ciri khas yang terdapat pada masa remaja yakni tingginya pengaruh lingkungan sekolah dan teman sebaya terhadap penentuan keputusan yang akan diambil. ${ }^{1}$ Remaja putri secara psikologis lebih memerhatikan penampilan fisik daripada remaja pria sehingga sangat memperhatikan pilihan pangannya. ${ }^{2}$
Permasalahan gizi yang umum terjadi pada remaja adalah kelebihan berat badan (overweight) dan obesitas. Overweight merupakan suatu kejadian yang kompleks dan disebabkan oleh multifaktor akibat adanya interaksi gaya hidup, lingkungan, dan genetik. $^{3} \quad$ Remaja merupakan aset dalam pembangunan sebuah Negara dan overweight dapat menurunkan produktivitas seperti penurunan nilai 
rata-rata prestasi belajar. Selain itu, anak dengan kegemukan bisa menurunkan tingkat kecerdasannya, karena aktivitas dan kreativitas menurun, serta cenderung menjadi malas. ${ }^{4}$

Hal tersebut dibuktikan dengan prevalensi overweight pada remaja umur 16-18 tahun pada putri lebih tinggi daripada pria yaitu $11,4 \%$ dan $7,7 \%$. Di Provinsi Sumatera Utara sendiri prevalensi overweight pada umur 16-18 tahun adalah 10,9\%. Angka tersebut jauh lebih tinggi daripada rata-rata nasional yakni 9,5\%. Salah satu penyebab dari overweight ialah asupan pangan yang dipengaruhi oleh pilihan pangan. Pangan yang dipilih merupakan refleksi dari berbagai faktor meliputi kebiasaan makan keluarga, pengaruh iklan/media digital, pengaruh teman sebaya dan lingkungan, serta ketersediaan makanan. ${ }^{5}$ Pilihan pangan yang tidak sehat pada remaja saat ini, salah satunya dipengaruhi oleh kurangnya pengetahuan gizi akibat dari penyampaian informasi kesehatan yang diberikan kurang sampai pada sasaran. ${ }^{6}$

Pedoman gizi seimbang merupakan susunan makan sehari-hari yang mengandung zat gizi dengan jenis dan jumlah yang sesuai kebutuhan tubuh disertai 4 prinsip di dalamnya. Pedoman gizi seimbang dibuat untuk menggantikan slogan "4 Sehat 5 Sempurna" yang dinilai sudah tidak relevan dengan masyarakat sekarang. Namun, PGS dirasa belum cukup familiar di masyarakat dikarenakan uraian ilmiahnya cukup tinggi dibandingkan dengan slogan "4 Sehat 5 Sempurna" (6). Hal tersebut sejalan dengan penelitian Fauzi yang dilakukan pada 11 siswa SMP dan didapatkan tidak ada siswa yang mengenal PGS dan lebih mengenal slogan "4 Sehat 5 Sempurna".

Penelitian Aini menemukan fakta bahwa responden memilih makanan tanpa memperhatikan apakah makanan tersebut bergizi seimbang atau tidak serta nilai-nilai PGS belum diketahui oleh sebagian besar responden. ${ }^{7}$ Sejalan dengan itu, hasil penelitian Ariani (2017) pada siswa SMA Bina Bangsa Bogor menyatakan bahwa informasi terkait PGS masih belum tersebar luas di masyarakat sehingga pengetahuan siswa terkait PGS masih rendah. ${ }^{8}$

Subjek pada penelitian ialah remaja putri berusia 16-18 tahun dan termasuk dalam kategori remaja tengah. Karakteristik yang sangat khas pada usia ini yakni adanya peningkatan kemampuan dalam membuat keputusan sendiri, sangat dipengaruhi oleh teman sebaya, serta lingkungan sosial, keadaan emosional, dan keuangan yang meningkatkan kemampuan remaja membuat keputusan sendiri yang berhubungan dengan asupannya. ${ }^{1}$ Penelitian ini bertujuan untuk mengetahui secara mendalam mengenai pengetahuan gizi seimbang terhadap perilaku pilihan pangan pada remaja putri overweight.

\section{METODE}

Penelitian ini menggunakan metode kualitatif yang fokus terhadap kualitas kedalaman data dan mengutamakan perspektif subjek penelitian. Jumlah partisipan yang terlibat dalam penelitan ialah 16 orang remaja putri berusia 16-18 tahun di Kelurahan Tegal Rejo, Kota Medan. Populasi ialah remaja putri berusia 16-18 tahun di Kelurahan Tegal Rejo. Penelitian dilakukan bulan April sampai Mei 2020.

Kriteria eksklusi penelitian ialah remaja putri yang memiliki riwayat penyakit metabolik yang menyebabkan overweight/obesitas, tidak mampu berkomunikasi dengan baik, serta keluar saat penelitian berlangsung dengan alasan apapun. Subjek penelitian dipilih dengan cara purposive dan snowball sampling. Jumlah subjek yang mengikuti penelitian ialah 16 orang ( 8 overweight dan 8 normoweight). Pemilihan subjek penelitian didasarkan pada kriteria berikut: berstatus gizi overweight dan normoweight, usia 16-18 tahun, uang saku $(<30.000 \& \quad>30.000$ per hari $)$, karakteristik orangtua (memasak/membeli pangan), perilaku konsumsi di sekolah (mengonsumsi pangan tidak sehat/tidak), serta terpapar terhadap media internet. Kriteria tersebut dipilih berkaitan dengan penelitian terdahulu dengan judul "Influences on eating: a qualitative study of adolescents in a periurban area in Lima, Peru. ${ }^{9}$

Pengumpulan data dilakukan dengan metode wawancara mendalam dan observasi. Data status gizi didapatkan dengan menimbang berat badan menggunakan timbangan injak digital, sedangkan tinggi badan diukur dengan mikrotoise. Pengetahuan gizi diambil menggunakan panduan wawancara mendalam berupa pertanyaan semi terstruktur yang dispesifikasi untuk remaja putri, guru sekolah, dan teman sebaya. Triangulasi sumber dilakukan dengan membandingkan dan mengecek balik derajat kepercayaan suatu informasi yang diperoleh melalui sumber yang berbeda. Dalam penelitian ini, dilakukan triangulasi sumber yakni dengan membandingkan data yang diterima dari informan utama dengan guru sekolah dan teman sebaya. Triangulasi tersebut dilakukan dengan mewawancarai secara mendalam teman sebaya dan guru sekolah dan dipandu dengan pertanyaan semi terstruktur. Food Photograph (gambar makanan) digunakan dalam penelitian ini untuk memperkuat perspektif subjek terhadap motivasi memilih pangan tertentu.

Kategori status gizi dikategorikan menjadi normoweight apabila Z-Score IMT/U -2SD s/d +1 SD sedangkan overweight yakni $>1 \mathrm{SD}$ s/d 2 SD. ${ }^{10}$ 
Analisis data diawali dengan mengubah rekaman suara menjadi transkrip berupa tulisan dengan bantuan Ms. Word 2013, selanjutnya tahap pengkodean (coding) menggunakan Ms. Excel 2013 untuk mendapatkan tema - tema yang menjelaskan hasil penelitian. Pengkodean terdiri dari level 1,2,3, dan 4, kemudian tema dibentuk dalam diagram untuk dilakukan interpretasi data sehingga mendapatkan penjelasan mengenai hasil temuan berdasarkan teori-teori ilmiah. Penelitian ini telah mendapatkan persetujuan dan kelayakan etik dari Komisi Etik Penelitian Kesehatan (KEPK) UPN Veteran Jakarta dengan Nomor: 2647/VI/2020/KEPK.

Pertanyaan semi terstruktur digunakan untuk membantu agar wawancara mendalam yang dilakukan tetap terfokus, diawali dengan memperkenalkan peneliti dan enumerator, begitupun dengan tujuan dan metode penelitian, perizinan untuk merekam proses wawancara dan menjelaskan persetujuan setelah pemberitahuan. Eksplorasi pengetahuan dan perspektif PGS diperoleh dengan menanyakan pendapat, pengetahuan, pilar-pilar, dan penenerapannya dalam pola makan sehari-hari. Pilihan pangan diidentifikasi dengan menanyakan kebiasaan jajan (snacking), pola sarapan hingga makan malam baik di sekolah maupun rumah disertai dengan menceritakan aktivitas sehari-hari subjek. Motivasi dalam memilih pangan diperkuat dengan menanyakan alasan memilih pangan tertentu seperti dana, pengaruh orangtua/teman, ketersediaan pangan, maupun media informasi. Pada akhir sesi, peneliti mengucapkan terimakasih dan memberikan souvenir.

\section{HASIL}

\section{Gambaran Umum Subjek}

Sebanyak 16 informan terlibat dalam penelitian ini, sebagian besar berusia 16 tahun, mengonsumsi pangan rendah gizi-tinggi energi, dan karakteristik orangtua informan sebagian besar mempersiapkan makanan sendiri dengan cara memasak di rumah. Proporsi overweight dan normoweight sama yakni $50 \%$, begitu juga dengan komposisi jumlah uang saku $(<30.000$ dan $>30.000)$ (Tabel 1).

Tabel 1. Karakteristik Informan

\begin{tabular}{lc}
\hline \multicolumn{1}{c}{ Karakteristik } & $\mathbf{n = 1 6 ( \% )}$ \\
\hline IMT (Indeks Massa Tubuh) & $8(50)$ \\
Overweight & $8(50)$ \\
Normoweight & $9(56,3)$ \\
Umur (tahun) & $5(31,3)$ \\
16 & $2(12,5)$ \\
17 & $8(50)$ \\
18 & $8(50)$ \\
Uang Saku (Rp/hari) & $14(87,5)$ \\
$<30.000$ & $2(12,5)$ \\
$>30.000$ & $13(81,3)$ \\
Karakteristik orangtua & $3(18,8)$ \\
Mempersiapkan makanan sendiri & $16(100)$ \\
Membeli makanan di luar rumah & \\
Ketersediaan pangan di sekolah & \\
Mengonsumsi makanan tinggi energi dan rendah nutrisi & \\
Mengonsumsi cemilan dari rumah dan membeli buah & \\
Keterpaparan pada media & \\
\hline
\end{tabular}

\section{Gambaran Pengetahuan PGS Subjek}

Seluruh informan (overweight dan normoweight) tidak mengenal pedoman gizi seimbang dan lebih familiar dengan istilah ' 4 sehat 5 sempurna'. Minimnya keterpaparan terhadap informasi PGS di sekolah maupun lingkungan pelayanan kesehatan (Puskesmas/Rumah sakit) menjadi alasan utamanya.

"Aku ga pernah dengar PGS. Kalau misalkan tentang 4 sehat 5 sempurna pernah dengar dari SD udah diajarin. Di RS dan Puskesmas tidak pernah lihat. Belum pernah ada penyuluhan tentang kesehatan atau gizi di sekolah" (Overweight, 16 tahun, uang saku $>30.000)$

"Pernah dengar tentang PGS. Menurut aku PGS sama 4 sehat 5 sempurna kayaknya sama deh. Hmmm kayak makan yang 4 sehat 5 sempurna gitu, makan di jam yang teratur, rajin makan buah. Belum pernah lihat gambar ini (tumpeng PGS)" (Normoweight, 16 tahun, uang saku <30.000)

Mereka merasa tidak diperkenalkan dengan informasi tersebut sehingga masih menganggap '4 sehat 5 sempurna' masih berlaku hingga sekarang. Peneliti juga menunjukkan gambar tumpeng gizi seimbang kepada seluruh informan, namun hasilnya 
tidak ada yang pernah melihat gambar tersebut sebelumnya di sekolah maupun lokasi pelayanan kesehatan lain seperti Puskesmas dan Rumah Sakit. Hal tersebut dapat terjadi karena remaja putri yang mengunjungi pelayanan kesehatan tidak memperhatikan lokasi sekitarnya terlebih lagi kurang adanya minat dan ketertarikan terhadap informasi kesehatan.

\section{Gambaran Perilaku Pilihan Pangan Remaja Putri Overweight dan Normoweight}

Berdasarkan hasil wawancara mendalam (overweight) didapatkan kelompok bahan makanan pokok yang paling banyak dipilih ialah bihun, nasi, dan kentang. Telur, sosis, dan daging ayam merupakan produk pangan hewani yang paling familiar, sementara untuk pangan sumber protein nabati ialah tahu dan tempe goreng. Untuk kategori sayur yang yang paling sering dikonsumsi ialah bayam dan kangkung, buah-buahan yang paling banyak dipilih ialah pisang, semangka, dan pepaya. Di kategori lain seperti susu dan minuman ternyata jus buah, teh, dan susu kental manis yang paling banyak dikonsumsi serta untuk kategori terakhir yakni jajanan masih didominasi oleh gorengan, es krim, pudding, dan mie ayam.

Tabel 2. Bahan Makanan Paling Banyak Dikonsumsi Informan Overweight

\begin{tabular}{|c|c|c|c|c|c|c|}
\hline \multirow{2}{*}{$\begin{array}{c}\text { Makanan } \\
\text { Pokok }\end{array}$} & \multicolumn{2}{|c|}{ Lauk } & \multirow{2}{*}{ Sayuran } & \multirow{2}{*}{ Buah } & \multirow{2}{*}{$\begin{array}{l}\text { Susu dan } \\
\text { Minuman }\end{array}$} & \multirow{2}{*}{ Jajanan } \\
\hline & Hewani & Nabati & & & & \\
\hline Bihun & Ikan segar & Tahu Goreng & Bavam & Pisang & Jus Buah & Gorengan \\
\hline Nasi & Telur & & Dayami & Semangka & Teh & Es Krim \\
\hline Kentang & $\begin{array}{c}\text { Sosis } \\
\text { Daging Ayam }\end{array}$ & $\begin{array}{l}\text { Tempe } \\
\text { Goreng }\end{array}$ & Kangkung & Pepaya & $\begin{array}{l}\text { Susu Kental } \\
\text { Manis }\end{array}$ & $\begin{array}{c}\text { Puding } \\
\text { Mie Ayam }\end{array}$ \\
\hline
\end{tabular}

Remaja putri overweight mengonsumsi cemilan lebih dari satu kali sehari serta jarang mengonsumsi sayur dan buah. Menyediakan cemilan di rumah menjadi kebiasaaan remaja bahkan jajanan tinggi kalori menjadi konsumsi hariannya.

"Biasanya di rumah selalu ada sediaan snack kaya keripik pisang, biskuit, terus roti. Kalau lagi di sekolah biasanya jajan bakso, cilok, dan martabak telor gitu. Udah kek gitu-gitu aja. Kalau jus jarang kalau lagi pengen aja. Kalau lagi istirahat kadang beli jus" (Overweight, 18 tahun, uang saku $>30.000$ ) "Emang kurang suka makan yg berat gt kak, gampang kenyang. Paling jajan gorengan 1 atau gitu" (Normoweight, 17 ahun, uang saku $<30.000)$

"Terus aku sih termasuk orang yg malas makan kadang kan terlalu banyak nyemil jadi malas makan gitu. Udah kenyang duluan. Misal jajan snack gitu kan sering gitu nyemil jadi udahlah malas makan aja kak. Aku jajan sehari bisa sepanjang hari sih nyemil terus tapi ga makan. Terus kalau makan malam kadang-kadang malas, karena malas aja gitu makan ga rasa lapar juga." (Normoweight, 16 tahun, uang saku $<30.000$ )

Tabel 3. Bahan Makanan Paling Banyak Dikonsumsi Informan Normoweight

\begin{tabular}{|c|c|c|c|c|c|c|}
\hline \multirow{2}{*}{ Makanan Pokok } & \multicolumn{2}{|c|}{ Lauk } & \multirow{2}{*}{ Sayuran } & \multirow{2}{*}{ Buah } & \multirow{2}{*}{$\begin{array}{l}\text { Susu dan } \\
\text { Minuman }\end{array}$} & \multirow{2}{*}{ Jajanan } \\
\hline & Hewani & Nabati & & & & \\
\hline Nasi & Ikan Segar & \multirow{2}{*}{ Tahu Goreng } & \multirow{2}{*}{ Bayam } & Pisang & Teh & Gorengan \\
\hline Biskuit & Telur & & & Semangka & Bubble tea & Donat \\
\hline Mie Instan & $\begin{array}{c}\text { Bakso } \\
\text { Daging Ayam }\end{array}$ & $\begin{array}{l}\text { Tempe } \\
\text { Goreng }\end{array}$ & $\begin{array}{c}\text { Wortel } \\
\text { Kangkung }\end{array}$ & $\begin{array}{l}\text { Jambu } \\
\text { Nanas }\end{array}$ & Jus buah & $\begin{array}{c}\text { Es Krim } \\
\text { Mie Bakso }\end{array}$ \\
\hline
\end{tabular}

Jika diperhatikan secara detail terdapat beberapa kemiripan antara pilihan pangan remaja putri overweight dan normoweight. Kemiripan tersebut dapat muncul karena lokasi tempat tinggal ialah di kelurahan yang sama memungkinkan variasi ketersediaan pangan tidak jauh berbeda. Hasil wawancara mendalam menunjukkan informan overweight mengonsumsi cemilan lebih dari satu kali sehari sementara 2 orang informan normoweight mengaku tidak terlalu suka mengonsumsi cemilan karena merasa sudah cukup kenyang dengan asupan makanan lengkap (nasi, lauk, sayur, buah).
Sementara 6 orang remaja normoweight lainnya lebih banyak mengonsumsi cemilan daripada makanan lengkap karena sudah cukup kenyang dengan cemilan. Bila dibandingkan, remaja putri overweight mengaku sering dan mengonsumsi cemilan namun juga tetap mengonsumsi makanan lengkap.

\section{Kebiasaan Sarapan}

Sarapan didefinisikan sebagai kegiatan makan dan minum yang dilakukan saat bangun pagi hari sampai pukul 9 pagi. Sebanyak 6 orang remaja putri overweight selalu sarapan sedangkan 2 orang 
lainnya (overweight) mengaku tidak terbiasa sarapan atau hanya mengonsumsi minuman tertentu di pagi hari.

"Sarapan biasanya nasi lemak, lontong disiram kuah gulai sayur, ikan tongkol karena mama kan jual nasi lemak di rumah" (Overweight, 16 tahun, uang saku >30.000)

"Kalau pagi sih harus sarapan kak, kalau engga pusing" (Normoweight, 17 ahun, uang saku <30.000)

Orangtua memiliki peran dalam membentuk perilaku sarapan pada anak dan terdapat informan yang mengaku tidak terbiasa sarapan bahkan melewatkan sarapan pagi.

"Kalau pagi biasanya ga sarapan kak, makannya nanti jam 1-an kayak makan nasi sama lauknya. Emang ga lapar gitu soalnya dah biasa" (Overweight, 18 tahun, uang saku $>30.000)$

"Sarapan keseringan makan roti di sekolah karena takut terlambat. Aku lebih sering yg dibeli luar dan paling sering beli ikan, nasi, dan sayur kaya nasi bungkus gitu kak karena mama kerja jualan gitu jadi ga sempat masak untuk pagi, siang dan malam" (Normoweight, 16 tahun, uang saku $<30.000$ )

Menu sarapan yang dianjurkan terdiri dari pangan sumber karbohidat, lauk pauk, sayur, buah, dan minuman. Menu sarapan yang dikonsumsi oleh remaja putri sebagian besar berdasarkan ketersediaan pangan di rumah mereka yang juga dipengaruhi oleh pekerjaan orangtua dan preferensi makanan keluarga. Menu sarapan cenderung dengan olahan digoreng atau disantan yang tinggi kalori memicu kelebihan berat badan pada remaja. Melewatkan sarapan tidak dianjurkan karena dapat meningkatkan keinginan untuk memuaskan hasrat makan lebih banyak di saat jam makan siang/malam serta frekuensi cemilan lebih tinggi.

\section{Konsumsi Air Putih}

Pedoman Gizi Seimbang menganjurkan konsumsi air putih yang aman dan cukup sebanyak \pm 8 gelas per hari per individu. Rata-rata dari mereka mengetahui anjuran tersebut dari pelajaran di sekolah, dari guru, maupun dari orangtua.

"Kalau minum air putih 8 gelas kan karna anjuran kesehatan kan kita butuh cairan jadi dianjurkan minum air putih 8 gelas" (Overweight, 17 tahun, uang saku >30.000)

Namun, kebanyakan informan mengaku belum mengonsumsi air putih dalam jumlah yang adekuat dikarenakan beberapa alasan seperti tidak menyukai rasa air putih yang hambar, pekerjaan/kegiatan tidak terlalu berat, hanya minum setelah makan, dan lebih memilih konsumsi minuman manis seperti bubble tea, teh manis, ataupun es kopi susu.

"Aku lebih suka minum bubble tea kak karena kan kalau air putih rasanya hambar aja, kalau jus aku ga terlalu suka sama rasa buah, jadi lebih suka bubble enak gitu. Jadi lebih banyak minum bubble tea daripada air putih. Teh manis juga sering minum setiap hari pas pagi-pagi udah terbiasa" (Overweight, 16 tahun, uang saku >30.000)

Aku minum air putih kurang dari 8 gelas karena kalau beresin rumah gitu ga terlalu berat jadi ga terlalu capek, minum itu kalau habis makan aja. Jadi ga pengen minumminum gitu. Di sekolah kalau makan jajanan aja baru minum, intinya kalau habis makan baru minum (Normoweight, 17 tahun, uang sak <30.000)

\section{Asupan Pangan Tinggi Gula}

Pedoman Gizi Seimbang menganjurkan konsumsi gula dalam sehari maksimal sebanyak 4 sendok makan. Namun, 3 dari 8 orang remaja putri overweight memiliki preferensi makanan ataupun minuman manis sementara sisanya sangat menyukasi rasa asin dan gurih.

"Aku lebih suka yang manis kak karena sering bikin pudding gitu. Biasanya yang distok jajanan itu ciki-ciki (snack ringan dalam kemasan), wafer, coklat gitu. Akukan juga sering buat makanan sendiri misal cemilan gitu kaya cookies-cookies gitu, pudding, brownies. Dari mama juga kak, kan mama kan suka masak, dan taruh resep di belakang" (Overweight, 16 tahun, uang saku $>30.000)$

Hal tersebut terjadi karena kebiasaan pola konsumsi yang terbentuk dalam keluarga sejak kecil. Keluarga merupakan tempat anak bertumbuh dan berkembang serta dibentuk untuk pertama kalinya. Pola asuh orangtua, pola makan, dan preferensi makanan keluarga akan sangat memengaruhi pembentukan perilaku pilihan pangan individu. Peranan orangtua sebagai penyedia pangan bagi anak memiliki peran penting dalam kebiasaan konsumsi pangan anak.

Asupan Pangan Tinggi Garam dan Lemak

Kebiasaan pola konsumsi ini terbentuk bukan tanpa dasar yang kuat. Sekolah merupakan tempat siswa banyak menghabiskan waktu, terlebih lagi banyaknya jajanan yang dijual memungkinkan sebagian besar konsumsi remaja berasal dari lokasi ini. Kantin sekolah menjual berbagai makanan ringan dan makanan berat. Biasanya gorengan, nasi bungkus, snack kemasan, biskuit, roti, dan berbagai minuman manis merupakan menu andalan pedagang. Sebagian besar informan (13 dari 16 
orang) mengakui preferensi pangan mereka ialah pangan dengan olahan digoreng (deep fried), menggunakan saos, cemilan gurih dan asin.

"Kalau makanannya suka makanan yang agak pedas sama asam terus ga suka makanan manis, ga terlalu suka makanan manis. Kalau dari segi penampilan suka makanan yg lebih ke junk food sih kak makanan cepat saji gitu. Kaya kebab, sate, itu ajasih yg sering dibeli. Kalau ga beli bakso juga. Karena lebih menarik selera untuk dimakan, gatau kenapa lebih enak gitu" (Overweight, 17 tahun, uang saku >30.000)

Pengaruh teman sebaya (peer pressure) dinyatakan seluruh remaja putri sebagai alasan mengonsumsi pangan tidak sehat di sekolah. Ketidakmampuan informan untuk menolak ajakan teman-temannya membuat mereka mengabaikan nasihat orangtua untuk mengonsumsi pangan sehat seperti jus buah, maupun buah potong seperti rujak. Mereka mengakui mengonsumsi makanan bersama teman sebaya terasa lebih asyik daripada makan sendirian karena dapat mengobrol hal-hal tertentu.

"Contoh jajannya itu ada gorengan yang ada penyedap rasanya, terus makan yang bersaos-saos. Di sekolah yang paling banyak dibeli sama siswa sosis bersaos gitu karena enak dan cocok dengan lidah anak sekolah aja gitu, pas jam istirahat makannya sama teman-teman sambil ngobrol" (Normoweight, 16 tahun, uang saku <30.000)

\section{Konsumsi Buah dan Sayuran}

Pedoman Gizi Seimbang menganjurkan sayur dan buah untuk hidup sehat sebanyak $400 \mathrm{~g}$ per orang/hari yang terdiri dari $250 \mathrm{~g}$ sayur (setara dengan $2 \frac{1}{2}$ gelas sayur setelah dimasak dan ditiriskan) dan $150 \mathrm{~g}$ buah (setara dengan 3 buah pisang ambon ukuran sedang atau $1 \frac{1 / 2}{2}$ potong pepaya ukuran sedang atau 3 buah ukuran sedang) untuk menjaga hidup sehat. ${ }^{11}$

Selama penelitian berlangsung didapatkan hasil bahwa hanya 1 orang remaja putri overweight yang menyebutkan sangat menyukai sayur dan buah meskipun tetap mengonsumsi pangan tidak sehat lainnya.

"Kalau aku suka banyak makan ikan daripada nasi dan sayur. Misalnya makan ikan bisa sampe 2 potong sedang sekali makan, nasinya cuman $1 / 2$ centong sayurnya yah paling $3 \mathrm{sdm}$ gitu. (Overweight, 16 tahun, uang saku >30.000)

Sama seperti rendahnya konsumsi sayur, konsumsi buah-buahan juga tidak jauh berbeda.

“...buah ga makan setiap hari karna

kadang-kadang udah terlalu kenyang makan nasi, ikan, terus minum air"
(Normoweight, 17 tahun, uang saku $>30.000$ )

Pernyataan tersebut menggambarkan bahwa konsumsi harian sayur dan buah harian informan belum memenuhi anjuran pedoman gizi seimbang.

\section{Konsumsi Sumber Protein Hewani dan Nabati}

Ikan segar menjadi sumber protein hewani yang paling dominan dapat disebabkan oleh kondisi geografis dari Kota Medan itu sendiri. Terdapat satu Pelabuhan yaitu Pelabuhan Belawan yang menjadi tempat pemasok ikan dari nelayan untuk memasarkan produknya ke berbagai daerah di wilayah ini. Di samping itu, harga ikan yang dijual sangat terjangkau dengan kualitas yang segar dan bagus membuat ibu remaja putri lebih memilihnya sebagai sumber protein hewani dan sumber protein nabati yang paling umum dikonsumsi ialah tahu dan tempe goreng.

“..lebih suka ikan laut karena kan kak yang sering dimasak di rumah itu dan kalau kaya telur atau ikan teri ga terlalu sering, jadi makan apa yang dimasak sama ibu aja. Dan kebetulan suka, jadi ya dimakan aku. Biasanya suka yang digoreng sama yang bersantan gitu kayak gulai sama yang digoreng" (Overweight, 16 tahun, uang saku $>30.000)$

Namun, olahan lauk hewani dan nabati diolah dengan cara digoreng yang cenderung mengandung kalori tinggi menjadi pilihan utama remaja putri.

\section{Komposisi Makanan Tidak Seimbang}

Komposisi makanan merupakan padupadanan berbagai sumber zat gizi dalam satu piring makan untuk memenuhi berbagai kebutuhan zat gizi individu. Kenyataan ini ternyata cukup memprihatinkan, seharusnya remaja putri sebagai subjek daur kehidupan yang akan menghasilkan generasi penerus bangsa, ternyata tidak berperilaku positif sesuai dengan pedoman gizi seimbang.

"Kalau aku suka banyak makan ikan daripada nasi dan sayur. Misalnya makan ikan bisa sampe 2 potong sedang sekali makan, nasinya cuman 1/2 centong sayurnya yah paling $3 \mathrm{sdm}$ gitu. (Overweight, 16 tahun, uang saku >30.000)

Meskipun begitu, berdasarkan pengakuan beberapa infoman sebenarnya orangtua telah menasihati mereka untuk mengonsumsi pangan yang dimasak oleh ibu di rumah daripada membeli makanan dan jajanan di luar rumah (rumah makan/pedagang jalanan) namun keterpaparan terhadap pangan jajanan yang dipersepsikan memiliki cita rasa "lezat dan memuaskan" menjadi alasan terbesar informan tidak mengikuti anjuran pedoman gizi seimbang disamping minimnya pengetahuan PGS. 
“...itulah kak udah dinasihati makan sayur dipaksa makan sayur ya belakangan ini makan sayurlah walaupun sedikit makan buah juga walaupun sedikit-sedikit ya hahah gitulah kak..." (Normoweight, 17 tahun, uang saku >30.000)

Perilaku konsumsi remaja saat ini merupakan hasil dari kebiasaan pola konsumsi sejak usia anak-anak sehingga hal tersebut harusnya menjadi perhatian bagi orangtua untuk membentuk perilaku konsumsi yang sehat

Pembacaan Label Pangan pada Kemasan Produk Label pangan berisi informasi mengenai isi, jenis, komposisi zat gizi, tanggal kadaluarsa, dan keterangan penting lainnya. Biasanya komposisi zat gizi yang paling atas dituliskan ialah kalori, lemak, karbohidrat, gula, dan protein per takaran saji.

"Sering kak kalau misalkan lagi makan gitu lihat-lihat bungkusnya dibalik-balik gitu. Cuma ga ngerti kak apa isi tulisannya asal makanin aja. Jadi makan tuh ga terlalu lihat komposisi, kandungan gizi yang penting suka aja sama rasanya" (Overweight, 16 tahun, uang saku >30.000)

"Kalau beli snack aku lihat tanggal expirednya aja ga pernah lihat komposisi atau nilai kandungan gizinya. Ya karna baik atau engga dikonsumsi dari tanggal expirednya. Komposisi sama nilai kandungan gizinya ga terlalu penting juga buatku, ya makan aja gitu" (Normoweight, 16 tahun, uang saku <30.000)

Diantara 16 orang informan hanya 1 orang saja yang memperhatikan jumlah kalori dalam produk pangan, sementara yang lainnya hanya membaca tanggal kadaluarsanya saja. Alasan utama yang membuat sebagian besar informan tidak membaca kandungan gizi dalam label ialah ketidaktahuan cara membaca label pangan bahkan ketidakpedulian terhadap jumlah kalori yang terdapat dalam sebuah produk karena mereka menganggap cita rasa dan hargalah yang menjadi faktor penentu pemilihan sebuah produk pangan.

\section{PEMBAHASAN}

Rendahnya keterpaparan PGS menjadi salah satu prediktor perilaku pilihan pangan remaja putri overweight tidak sesuai dengan anjuran PGS. Saat ditunjukkan gambar tumpeng gizi seimbang kepada seluruh informan, tidak ada yang pernah melihat gambar tersebut sebelumnya di sekolah maupun lokasi pelayanan kesehatan lain seperti Puskesmas dan Rumah Sakit. Jika diperhatikan secara detail, komposisi kepadatan informasi dan pesan pada PGS memang lebih kompleks, hal tersebut terjadi karena aspek-asek yang ingin disampaikan melalui gambar tumpeng PGS lebih luas dan menyeluruh. PGS lahir karena konsep 4 sehat 5 sempurna dianggap tidak lagi relevan dengan kehidupan di era modernisasi.

Hasil wawancara mendalam menunjukkan remaja putri overweight mengonsumsi cemilan lebih dari satu kali sehari. Jika ditinjau lebih dalam, sebenarnya perilaku pilihan pangan diantara remaja putri baik overweight maupun normoweight tidak terlalu berbeda jauh. Hal ini dikarenakan lingkungan tempat tinggal dan varietas pangan di sekolah informan juga tidak jauh berbeda. Berdasarkan pengakuan informan, perbedaan frekuensi makan dan cemilanlah yang paling menonjol. Penelitian yang dilakukan oleh Suryaputra (2012) mengemukakan bahwa remaja dengan status gizi lebih memiliki frekuensi makan yang lebih tinggi daripada remaja dengan IMT normal. Frekuensi makan yang tinggi dapat menyebabkan kelebihan asupan sehingga menimbulkan penumpukan lemak. Meskipun golongan cemilan yang diminati cenderung sama yakni gorengan, bakso, sosis, dan es krim namun perbedaannya ialah frekuensi konsumsi. ${ }^{12}$ Cemilan menyumbang energi namun tidak dengan zat gizi dan didukung remaja suka mengemil sehingga berpotensi menyebabkan gizi lebih. Namun, asupan kalori informan tidak dapat digambarkan melalui data kualitatif.

Beberapa Negara Barat telah mengupayakan tindakan preventif terjadinya gizi lebih melalui pendekatan dengan sekolah. Sekolah diwajibkan memiliki kebijakan mengenai penyelenggaraan kantin sehat serta memaksimalkan perannya dalam menyebarluaskan konsumsi pangan sehat untuk siswa. ${ }^{13}$

National Longitudinal Study of Adolesent Health melaporkan bahwa kebiasaan mengonsumsi sarapan mengurangi risiko terjadinya overweight dan obesitas pada remaja dan dewasa dibandingkan mereka yang suka melewatkan sarapan (skipping breakfast habit). Ternyata sejumlah penelitian mengungkapkan berbagai akibat dari melewatkan sarapan. Pertama, melewatkan sarapan mengubah nafsu makan dan menurunkan efek kenyang sehingga akan meningkatkan keinginan untuk mengonsumsi lebih banyak makanan pada jam makan siang atau saat jam istirahat sekolah karena adanya perubahan sensitivitas insulin. ${ }^{14,15}$ Kedua, melewatkan sarapan meningkatkan risiko gizi lebih berkaitan dengan pengaruhnya terhadap hormon tubuh. Sarapan dapat meregulasi level glukosa dalam tubuh individu yang sehat karena reaksi insulin. Ditambah lagi, studi klinis menunjukkan individu yang melewatkan sarapan dikaitkan dengan pelepasan hormon stress yang berlebihan oleh 
hypothalamic pituitary adrenal (HPA $)^{3}$ karena terganggunya ritme kortisol..$^{15,16}$

Studi kualitatif Annisa, Indriasari \& Yustini menemukan bahwa menu sarapan yang dikonsumsi remaja putri overweight cenderung berkalori tinggi (energy dense food). Menu sarapan dengan kalori tinggi yang telah dibuktikan oleh riset identik dengan peningkatan berat badan (13). Tidak berbeda dengan penelitian kualitatif Iriantika pada remaja putri di Surabaya yang menemukan bahwa menu sarapan pada remaja overweight cenderung menimbulkan kenaikan berat badan seperti ayam goreng, ikan goreng, tempe dan tahu goreng serta pisang karamel. Remaja percaya bahwa pangan yang bercita rasa gurih, pedas, dan digoreng yang dijual oleh pedagang jalanan lebih dapat diterima daripada pangan yang dimasak di rumah. ${ }^{19}$

Penelitian Aprillia et al. menemukan bahwa sebagian besar jajanan tidak sehat (tinggi natrium, tinggi gula, dan tinggi lemak) paling banyak tersedia di sekolah/sekitar sekolah. Sebagian besar remaja putri tidak memerhatikan label pangan saat membeli produk. Siswa sekolah menganggap rasa lebih penting daripada kandungan gizi dalam membeli jajanan dan ketersedian pangan di sekolah merupakan salah satu faktor dalam menentukan perilaku pilihan pangan sehat atau tidak..$^{21,22}$

Konsumsi sayur dan buah sebagai sumber serat masih terbilang rendah pada remaja putri overweight. Sayur dan buah jika dikonsumsi secara simultan dengan perilaku gizi seimbang dapat menurunkan berat badan individu yang overweight karena pangan tersebut mengandung kadar air tinggi, rendah lemak, dan serat yang berperan dalam mengurangi asupan kalori makanan, sehingga secara konsekuen menurunkan berat badan. Serat pangan larut dapat menunda waktu pengosongan lambung dan membentuk struktur gel di usus halus sehingga meningkatkan aktivitas enzim pencernaan dan absorpsi makronutrien, memperpanjang waktu kontak antara zat gizi dan reseptor di usus halus, misalnya fruktosa, yang melepas putative satiety peptides. Hal tersebut menyebabkan kondisi hiperosmolaritas di kolon, tertariknya cairan ke dalam lapisan pencernaan, serta pada akhirnya menghilangkan nafsu makan yang berlebihan. ${ }^{23}$

Informasi nilai gizi dianggap membingungkan sebagian besar konsumen terutama anak-anak dan remaja karena ketidakpahaman terhadap maksud dari pesan tersebut. Hal ini membuat sejumlah konsumen memilih untuk membeli produk-produk tertentu yang familiar dengan lidah mereka yang kebanyakan memiliki kadar gula, karbohidrat, dan natrium tinggi per takaran sajinya. ${ }^{24}$
Konsumsi air putih yang adekuat dan aman diatur dalam pedoman gizi seimbang karena berdasarkan hasil penelitian mengonsumsi air putih dapat memperbaiki performa kognitif dan peningkatan konsentrasi pada remaja. Air merupakan bagian krusial dan penting bagi kesehatan manusia berkaitan dengan fungsinya dalam sebagian besar proses fisiologis tubuh, regulasi temperatur, dan pembuangan sisa metabolisme tubuh. ${ }^{25,26}$ Air putih juga merupakan minuman yang paling baik untuk menjaga hidrasi dibandingkan minuman lainnya. Selain itu, mengonsumsi air putih lebih dianjurkan daripada mengonsumsi jenis minuman lain seperti minuman manis, soda, kopi, dan teh karena dapat mengurangi risiko terjadinya kelebihan asupan kalori pada remaja putri. Minuman berpemanis berpotensi menambah asupan kalori jika dikonsumsi sepanjang hari. $^{27}$

\section{SIMPULAN}

Karakteristik remaja putri tidak mengenal pedoman gizi seimbang dan belum memiliki pengendalian diri yang baik terhadap perilaku konsumsi pangan. Pilihan pangan pada remaja putri overweight dan normoweight masih belum optimal disebabkan lebih tingginya konsumsi pangan padat energi-rendah gizi seperti deep fried food, cemilan gurih, manis, dan asin, serta minimnya asupan sayur dan buah. Selain itu, pilihan pangan diantara mereka tidak terlalu berbeda jauh. Beberapa informan telah berperilaku sesuai anjuran PGS seperti terbiasa sarapan, minum air putih cukup dan aman, dan mengonsumsi lauk hewani tinggi protein. Sementara beberapa informan memiliki kebiasaan melewatkan sarapan, tidak membatasi konsumsi gula, garam, dan minyak, hanya membaca tanggal kadaluarsa pada label pangan, dan kurang mengonsumsi sumber serat.

Selain itu, penelitian selanjutnya disarankan untuk mewawancarai orangtua remaja putri karena berdasarkan teori dan hasil temuan perilaku individu yang terbentuk sekarang banyak dipengaruhi oleh kepercayaan, keyakinan, persepsi, dan pengetahuan orangtua terutama ibu sebagai penyangga penyediaan pangan keluarga.

\section{DAFTAR PUSTAKA}

1. Putro KZ. Memahami Ciri dan Tugas Perkembangan Masa Remaja. Aplikasia. 2017;17:25-32.

2. Solistiawati A, Sitasari NW. Hubungan antara citra tubuh dengan harga diri remaja akhir putri ( studi pada mahasiswi reguler universitas esa unggul ). Jurnal Psikologi Media Ilmiah psikologi.2015; 13(1):13-20. 
3. Nurdzulqaidah R, Perilaku Gizi Seimbang. Fakultas Kedokteran Universitas Islam Bandung. 2017.

4. Antono SD. Perbedaan prestasi belajar antara siswa obesitas dan tidak obesitas pada siswa sekolah dasar di kota kediri J Ilmu Kesehat. 2017;5(2):84-90.

5. Yuliah Y, Adam A, Hasyim M. Konsumsi sayur dan buah dengan kejadian obesitas pada remaja di Sma Negeri 1 Mamuju tahun 2016. Jurnal Kesehatan Manarang. 2017;3(1):3-6.

6. Fauzi CA. Analysis of The Knowledge and Behaviour of Adolescents Based on The General Guidelines of Balanced Nutrition ( PUGS ) Point 6, 10, 11, and 12. 2012

7. Aini SN. Faktor risiko yang berhubungan dengan kejadian gizi lebih pada remaja di perkotaan. Unnes J Public Health. 2013;2(1).

8. Ariani R. Perilaku gizi terkait pedoman gizi seimbang dan kaitannya dengan status gizi dan kesehatan siswa sma bina bangsa sejahtera bogor .Institut Pertanian Bogor. Skripsi. 2017.

9. Banna JC, Buchthal OV, Delormier T, Creedkanashiro HM, Penny ME. Influences on eating: a qualitative study of adolescents in a periurban area in Lima, Peru. BMC Public Health [Internet]. 2016;1-11.

10. Kementerian Kesehatan RI. Peraturan menteri kesehatan republik indonesia nomor 2 tahun 2020. Jakarta: Kementrian Kesehatan Republik Indonesia; 2020. p. 1-78.

11. Kementerian Kesehatan RI. Pedoman gizi seimbang. Jakarta: Kemenkes; 2014.

12. Suryaputra K, Nadhiroh SR. Perbedaan pola makan dan aktivitas fisik antara remaja obesitas dengan non obesitas. Makara Kesehatatan. 2012;16(1):45-50.

13. Maddah M, Nikooyeh B. Factors associated with overweight in children in Rasht, Iran: Gender, maternal education, skipping breakfast and parental obesity. Public Health Nutrition. 2009;13(2) : 196-200.

14. Önnerfält J, Albertsson CE, Montelius C, Jerneck KT. Obese children aged 4-6 displayed decreased fasting and postprandial ghrelin levels in response to a test meal. Acta Paediatr. 2018;107(3): 523-528.

15. Ma X, Chen Q, Pu Y, Guo M, Jiang Z, Huang $\mathrm{W}$, et al. Skipping breakfast is associated with overweight and obesity: A systematic review and meta-analysis. Obes Res Clin Pract. 2020;14(1): 1-8.

16. Jakubowicz D, Wainstein J, Ahren B, Landau Z, Bar-Dayan Y, Fray O. Fasting until noon triggers increased postprandial hyperglycemia and impaired insulin response after lunch and dinner in individuals with type 2 diabetes: a randomized clinical trial. Diabetes Care. 2015; 38(10): 1820-6.

17. Annisa N, Indriasari R, Yustini. Persepsi remaja tentang obesitas dan perilaku makan terkait obesitas di Sma Katolik Cendrawasih Makassar. 2015.

18. Iriantika KA, Margawati A. Studi kualitatif pengaruh pemberian konseling gizi terhadap perubahan sikap dan pemilihan makan pada remaja putri overweight. Journal of Nutrition College. 2017;6(1): 19-27.

19. Islam MR, Trenholm J, Rahman A, Pervin J, Ekström EC, Rahman SM. Sociocultural influences on dietary practices and physical activity behaviors of rural adolescents. Nutrients. 2019;11(12): 2916.

20. Aprillia BA. Faktor yang berhubungan dengan pemilihan makanan jajanan pada anak sekolah dasar. Universitas Diponegoro. Skripsi.2011.

21. Kabir A, Miah S, Islam A. Factors influencing eating behavior and dietary intake among resident students in a public university in bangladesh: a qualitative study. PLoS One. 2018;13(6):1-17.

22. Chi-Ming H, Wei L, Hsiao-Chi Y, Wen-Harn P. The relationship between snack intake and its availability of 4 th -6 th graders in Taiwan. Asia Pac J Clin Nutr. 2007;16(June):547-53.

23. Bolori P, Setaysh L, Rasaei N, Jarrahi F. Adherence to a healthy plant diet may reduce inflammatory factors in obese and overweight women-a cross-sectional study. Diabetes Metab Syndr. 2019;13(4): 2795-2802.

24. Georgina Russell C., Burke P.F., Waller D.S, Wei E. et al. The impact of front-of-pack marketing attributes versus nutrition and health information on parents' food choices. Appetite. 2017; $116: 323-338$.

25. Bogart LM, Ph D, Babey SH, Ph D, Patel AI, D $M$, et al. Lunchtime school water availability and water consumption among california adolescents. J Adolesc Health. 2016;58(1):98103.

26. Kenney EL, Long MW, Cradock AL, Gortmaker SL. Prevalence of inadequate hydration among us children and disparities by gender and race / ethnicity : national health and nutrition examination survey , 2009 - 2012. Am J Public Health. 2015;105(8):2009-12.

27. Ernovitania Y, Sumarmi S. Hubungan antara pengeluaran untuk minum dan pola konsumsi air dengan status hidrasi pada siswi SMP Unggulan Bina Insani. Indonesian Journal of Public Health. 2017;12(No.2, December):27685. 